\title{
MICROMOUSE LABIRINTUS TÉRKÉPEZŐ ROBOT TERVEZÉSE
}

\author{
Szinai Tünde \\ hallgató, Miskolci Egyetem, Automatizálási és Infokommunikációs Intézet \\ 3515 Miskolc, Miskolc-Egyetemváros, e-mail: szinai2@freemail.hu \\ Bartók Roland \\ tanársegéd, Miskolci Egyetem, Automatizálási és Infokommunikációs Intézet \\ 3515 Miskolc,Miskolc-Egyetemváros, e-mail:qgeroli5@uni-miskolc.hu
}

\begin{abstract}
Absztrakt
A Micromouse verseny egy eredetileg Japánból indult mára világszerte ismert és népszerü robotverseny. A feladat egy olyan robot tervezése, amely képes a verseny szabályainak megfelelö labirintus önálló feltérképezésére, majd a célterület elérésére a lehetö legrövidebb idön belül. A cikkben egy ilyen autonóm robot mechanikai és elektronikai tervezése kerül bemutatásra.
\end{abstract}

Kulcsszavak: micromouse, mobil robot, beágyazott rendszerek, mechatronikai rendszerek

\section{Abstract}

The Micromouse competition, originally from Japan, is now a world-famous and popular robot competition. The task is to design a robot that is able to independently map the maze according to the rules of the competition and then reach the target area in the shortest possible time. The article presents the mechanical and electronic design of such an autonomous robot.

Keywords: micromouse, mobile robot, embedded systems, mechatronic systems

\section{Bevezetés}

Donald Christiansen nevéhez köthető a Micromouse robot, valamint a verseny ötletének kigondolása. 1977-ben az IEEE Spectrum magazinban hívta ki a magazin olvasóit egy versenyre, felhívva öket arra, hogy tervezzenek és építsenek egy autonóm labirintus megoldó robotot, amelyet Micromouse néven ismertetett. A labirintus konfigurációja a verseny kezdetéig ismeretlen volt. A robotok próba köröket futhattak, hogy megismerjék a pályát, tanuljanak a teszt körökből. Ez segített abban, hogy az éles verseny körben az optimális utat kiválasztva, a legrövidebb idő alatt eljussanak a kijelölt célhoz a labirintusban.

Az első verseny után számos helyen rendeztek kisebb versenyeket a következő években. 1985-ben világverseny szintjére lépett, ekkor rendezték meg Japánban az elsőt. Innentől kezdve, a világ különböző pontjain tartanak ilyen versenyeket napjainkig. Magyarországon a Budapesti Müszaki és Gazdaságtudományi Egyetem ad színhelyet a megmérettetésre.

A technika és elektronika fejlödésének következtében egyre kisebb méretekben vált megvalósíthatóvá a robotok kivitelezése. Emiatt két kategóriára bomlott a verseny. A hagyományos méretü robotok mellett, amelyek Micromouse néven ismertek, megjelent a kisméretü robotok Half-size Micromouse kategóriája. Utóbbi esetén a pálya mérete is felére csökkent egyidejűleg a robotok méretének változásával. A két ágra két különböző verseny szabályzat vonatkozik, de a cél ugyanaz maradt, a lehető legrövidebb idö alatt megkeresni a kijelölt helyet az útvesztöben [1]. 


\section{A verseny szabályrendszere}

Az alábbi bekezdésekben a szabályok a robot tervezésének bizonyos szempontjai alapján csoportosítva kerülnek leírásra, hogy láthatóvá váljék, milyen megkötések vonatkoznak a tervezési fázisra, és ezek közül némelyikre milyen megoldások jöhetnek szóba.

A robotnak teljesen autonómnak kell lennie. A verseny alatt a meglévő hardver és szoftver felépítésén nem lehet változtatni [2]. Az irányításra és szabályozásra autonóm eszközöket kell alkalmazni, mivel nem lehetséges a kommunikáció a robottal és önállóan kell müködnie. A pálya felderítésére, valamint az optimális út kiválasztására algoritmus használata szükséges. Leggyakrabban Dijkstra algoritmusát, a flood-fill vagy az A* algoritmust használják az ilyen versenyeken.

A robot nem ugorhat át falakat, nem mászhat fel rájuk. Nem jelölheti meg a falakat és padlót maga után, semmilyen esetben sem. Nem hagyhat rajtuk nyomokat, karcokat és sérüléseket [2]. A szabályok alapján, érintésmentes érzékelők használata javallott leginkább. Az érzékelés megvalósítható ultrahang szenzorral, mivel a labirintus falai jó fényvisszaverő tulajdonságú fehér színủ mủanyagok. A sötét színü, matt, fából készült padlózat pedig kevéssé zavaró hatású az ultrahangos és optikai távolságmérés szempontjából. Ezekből is következik az, hogy jól alkalmazhatóak optoelektronikai szenzorok is, mint az infravörös távolságérzékelők. Más módszer lehet még az érzékelésre a gépi látás egészen kis kamerákkal, ilyen megoldás lehet például a line scan kamerák alkalmazása.

A robot magasságára nincs korlátozás, viszont a robot vetülete a padlóra nézve bele kell, hogy férjen egy négyzetbe, amelynek oldalhosszúsága $12,5 \mathrm{~cm}$. A labirintus $9 \mathrm{~cm}$ x $9 \mathrm{~cm}$ egységnégyzetekből épül fel [2]. Az 1. ábra a szabályzatban szereplő négyzeteket és falakat szemlélteti a méretükkel együtt.

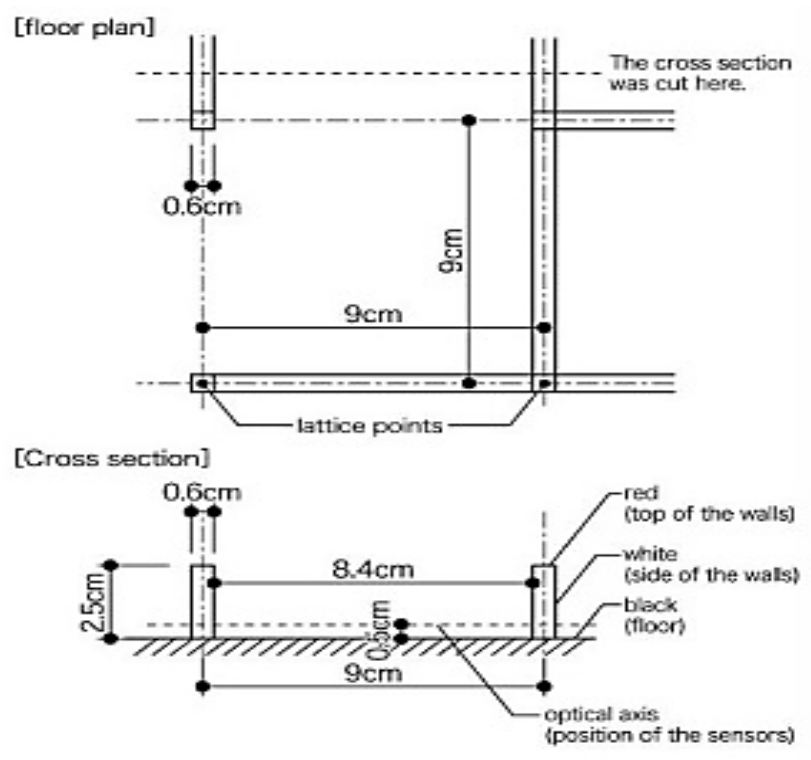

\section{1. ábra. A pálya felépitése}

A labirintus méreteire vonatkozó szabályok nagymértékben befolyásolják a robot méreteit is. A robotnak olyan méretekkel kell rendelkeznie, hogy dinamikusan és könnyedén tudjon mozogni a labirintusban. A legkritikusabb mozgás a $360^{\circ}$-os fordulat, hiszen ez adja a legkevesebb teret a mozgás megvalósításához. Feltételezhető, hogy ha ebben a helyzetben el tud fordulni a robot kényelmesen, akkor a pálya többi szakaszán is bőven elfér. 


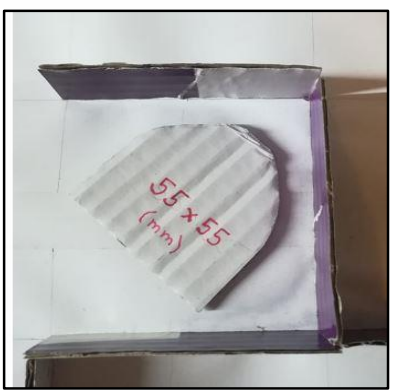

$55 \times 5.5$ mm-es alan

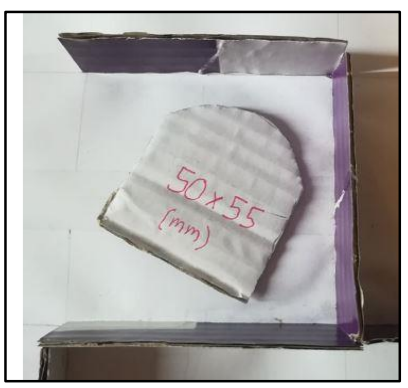

$50 \times 55$ mm-es alap

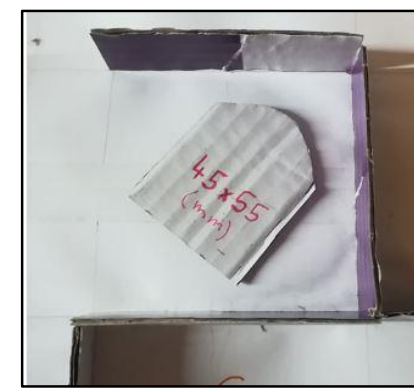

$45 \times 55$ mm-es alan

\section{2. ábra. A különbözö méretü alaplapok helyigénye}

Három méretben készült el egy sematikus robot alap. Az alapok felhasználásával ellenőrizhető, hogy melyik méret megfelelő a kritikus helyzetben. Az alapok olyan pozícióba kerültek elhelyezésre, amelyben a lehető legszükebben férnek el a cellában: lásd: 2. ábra. A választott alap mérete, amelyre az alkatrészek kerülni fognak $45 \mathrm{~mm}$ x $55 \mathrm{~mm}$.

\section{A mobil robot tervezése}

A robothoz szükség van áramellátó rendszerre, mikrokontrollerre, egy vagy több motorra, motorvezérlésre és motorszabályozásra, a hajtáshoz valamilyen hajtómüre és kerekekre, szenzorokra az érzékeléshez, valamint fontos biztosítani ezeknek a részegységeknek az egymás közötti megfelelő kommunikációját. Ezek egymáshoz való viszonyát mutatja be az alábbi, 3. ábra a [3] alapján.

\subsection{A motor méretezése}

Háromféle motor típus alkalmazható a robothoz. Mindegyiknek vannak előnyeik és hátrányaik. Ezeket gondosan összevetve és figyelembe véve a személyes igényeket, kiválasztható az ideális motor. A három motor elönyeit és hátrányait a következő táblázat mutatja.

Az 1. táblázat által összefoglaltak alapján a DC motort választottam. Szükséges az, hogy sokféle lehetőség közül lehessen választani, mivel kevés a hely. Erős és nagy indítónyomatékkal rendelkezik, amely szintén fontos egy Micromouse robotnál. Így két darab DC motor lesz beleépítve a robotba.

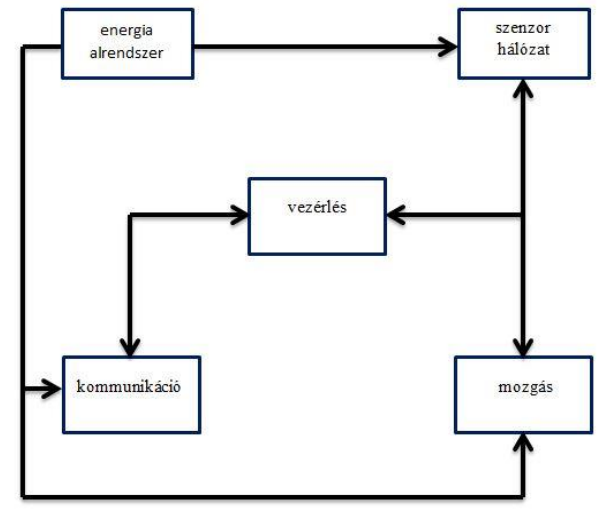

3. ábra. A robot blokkdiagramja 
1. táblázat. Motortípusok összehasonlitása [3]

\begin{tabular}{|c|c|c|}
\hline DC motor & Szervomotor & Léptető motor \\
\hline $\begin{array}{l}\text { Elönyök: } \\
{[1] \text { sokféle választék }} \\
{[2] \text { erős }} \\
{[3] \text { nagy indítónyomaték }} \\
{[4] \text { viszonylag olcsó a többihez }} \\
\text { képest } \\
\text { Hátrányok: } \\
\text { • külön hajtómü szükséges } \\
\text { hozzá } \\
\text { - külön motorvezérlés és sza- } \\
\text { bályozás }\end{array}$ & $\begin{array}{l}\text { Előnyök: } \\
\text { [5] tartalmazza a hajtómủvet és } \\
\text { vezérlést } \\
\text { [6] nagy hatásfok } \\
\text { Hátrányok: } \\
\text { [7] legdrágább } \\
\text { [8] nem olyan erős }\end{array}$ & $\begin{array}{l}\text { Előnyök: } \\
\text { • pontos pozicionálás } \\
\text { • olcsóbb, mint a szervomotor } \\
\text { Hátrányok: } \\
\text { [9] bonyolultabb vezérlés } \\
\text { [10] kisebb hatásfok }\end{array}$ \\
\hline
\end{tabular}

\subsubsection{A maximális sebesség és gyorsulás meghatározása}

A maximális gyorsulás és sebesség a 2014-2018-as évek labirintusainak elrendezései alapján kerültek meghatározásra. A pályát alkotó egyenes szakaszok hosszát a 2. táblázat foglalja össze. Ez nem tartalmazza az átlós szakaszokat, mert elhanyagolható a normál egyenes szakaszokhoz képest.

2. táblázat. Az eddigi versenyeken az egyenes szakaszok átlagos hossza

\begin{tabular}{|c|c|c|c|c|c|c|}
\hline & 2014 & 2015 & 2016 & 2017 & 2018 & Átlag \\
\hline $\begin{array}{c}\text { leghosszabb } \\
\text { egyenes szakasz }\end{array}$ & $1,884 \mathrm{~m}$ & $1,794 \mathrm{~m}$ & $1,794 \mathrm{~m}$ & $1,884 \mathrm{~m}$ & $0,984 \mathrm{~m}$ & $1,668 \mathrm{~m}$ \\
\hline
\end{tabular}

A robot sebessége úgy került meghatározásra, hogy a leghosszabb egyenes szakaszt 1 másodperc alatt képes legyen megtenni az alábbi összefüggés szerint:

$$
v=\frac{s}{t}=\frac{1,688 m}{1 \mathrm{~s}}=1,688 \frac{\mathrm{m}}{\mathrm{s}} \cong 1,7 \frac{\mathrm{m}}{\mathrm{s}}
$$

ahol $\mathrm{v}$ a robot sebessége, $\mathrm{s}$ a távolság, jelen esetben az átlagos legnagyobb távolság és $\mathrm{t}$ az idő, jelen esetben az s út megtételéhez kívánt idő.

A labirintusokban leggyakoribb egyenes szakasz hossza az 1 cella hosszú és az átlós távolságokat leszámítva 0,309 m. Ezek alapján a gyorsulás a számú alap összefüggésekböl:

$$
\begin{gathered}
s=v_{0} \cdot t+\frac{1}{2} \cdot a \cdot t^{2} \\
a=\frac{\Delta v}{\Delta t}=\frac{v-v_{0}}{\Delta t}=\frac{v-v_{0}}{t}
\end{gathered}
$$




$$
t=\frac{v-v_{0}}{a}
$$

ahol s a távolság, $v_{0}$ a kezdősebesség, $\mathrm{t}$ az eltelt idő, a gyorsulás kifejezve a $v$-t feltételezve, hogy $v_{0}^{2}=0$ :

$$
a=\frac{v^{2}}{2 \cdot s}=\frac{\left(1,7 \frac{\mathrm{m}}{\mathrm{s}}\right)^{2}}{2 \cdot 0,309 \mathrm{~m}}=4,68 \frac{\mathrm{m}}{\mathrm{s}^{2}}
$$

A robot a meghatározott sebesség eléréséhez számított gyorsulása tehát 4,68 m/s 2 .

\subsubsection{A robot tömege}

A robot tervezési fázisában a lehetséges alkatrészek még nem állnak rendelkezésre, ezért az adatlapok adatai alapján egy becsült tömeget lehet meghatározni:

- $\quad$ IR szenzor tömege (katalógus szerint) $\approx 10 \mathrm{~g}, 5$ darab $\rightarrow \underline{50 \mathrm{~g}}$

- Két darab DC motor hajtómúvel, enkóderrel, H-híd motorvezérlővel $\approx 406 \mathrm{~g}$

- Giroszkóp (ha lesz benne) $\approx \underline{3 \mathrm{~g}}$

- Lítium polimer akkumulátor $\approx 3 \mathrm{~g}, 2$ darab $\rightarrow \underline{6 \mathrm{~g}}$

- Váza a robotnak (NYÁK, kerék, görgö, stb.) $\approx 30 \mathrm{~g}$

Egyéb (csatlakozók, LED, kábelek, mikrokontroller) $\approx 5 \mathrm{~g}$

Összesen tehát a robot becsült tömege $500 \mathrm{~g}$. Ezzel meghatározhatók a motor paraméterei.

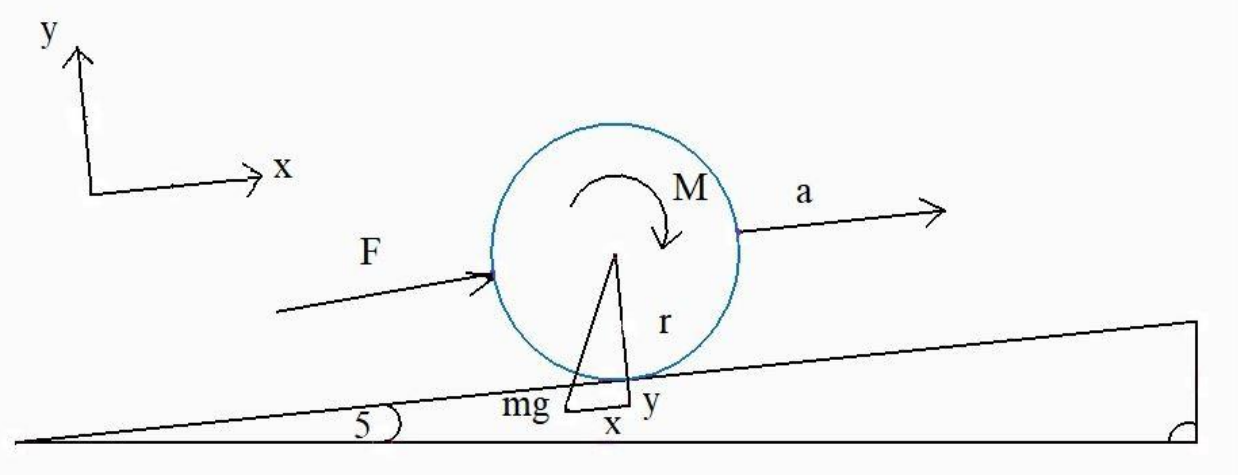

4. ábra. Nyomaték segédábra

\subsubsection{A motor paraméterei}

A robot sebessége és gyorsulása valamint a tömeg ismeretében kiszámíthatók a motor paraméterei. A motor nyomatékának kiszámításához figyelembe kell venni a pálya legnagyobb emelkedését, amely $5^{\circ}$. A felhasznált kerék $15 \mathrm{~mm}$ átmérőjü, amelynek a sugara 7,5 $\mathrm{mm}$. A motor nyomatéka az alábbi ábra alapján került meghatározásra (4. ábra): 
A motor nyomatéka a (6) számú képlettel került kiszámításra. A katalógusadatok alapján 65 \%-os átlagos motorhatásfokkal lehet számolni. Mivel a roboton két motor lesz, így a szükséges nyomaték a két motoron egyenlő mértékben oszlik szét:

$$
M=n \frac{r \cdot m \cdot(a+g \cdot \sin \alpha)}{2}=0,0156 \mathrm{Nm}
$$

ahol $\mathrm{M}$ a kívánt nyomaték egy motorra vetítve, $\mathrm{n}$ a hatásfok, $\mathrm{r}$ a kerék átméröje, $\mathrm{m}$ a robot tömege, az a a robot kívánt gyorsulása, g a gravitációs gyorsulás, $\alpha$ pedig a pálya maximális dőlésszöge.

A maximális sebességhez tartozó fordulatszám 2164,50 fordulat percenként, amely 226,67 $\frac{\mathrm{rad}}{\mathrm{s}}$ szögsebességnek felel meg. A motor szükséges teljesítménye a fordulatszám és a nyomaték alapján 1,5szeres biztonsági tényezővel:

$$
P=1,5 \cdot M \cdot \omega=0,01596634 \mathrm{Nm} \cdot 226,67 \frac{\mathrm{rad}}{\mathrm{s}}=5,42865 \mathrm{~W}
$$

ahol az M a számított forgatónyomaték, $\omega$ pedig a számított szögsebesség.

Ezek alapján a motor árama a 3 V-os tápfeszültségen:

$$
I=\frac{M \cdot \omega}{U}=\frac{0,01596634 \mathrm{Nm} \cdot 226,67 \frac{\mathrm{rad}}{\mathrm{S}}}{3 \mathrm{~V}}=1,20636 \mathrm{~A}
$$

ahol I a motor árama, M a számított forgatónyomaték, $\omega$ a motor szögsebessége, U a motor minimális tápfeszültsége.

A motor esetén előnyös egy olyan példány használata, amely már tartalmaz útjeladót is, amellyel érzékelhető a megtett út és a robot pillanatnyi sebessége.

\subsubsection{Az akkumulátor kapacitása}

Mivel a motor a legnagyobb fogyasztó a rendszerben, fél órás müködéshez a két motor számára elegendő meghatározni az akkumulátor kapacitását, amely így körülbelül 1,2 Ah. Az energiát könnyủ és nagy árammal terhelhetô Lítium polimer akkumulátor biztosítja.

\subsubsection{Mikrovezérló}

A robot központi vezérlője egy Cypress CY8C5868AXI-LP035 [6] típusú PSoC, amely 256 kB flash memóriát és 64 kB RAM-ot tartalmaz. Előnye, hogy az M3 ARM mikrovezérlő mellett tartalmaz egy konfigurálható digitális blokkot és egy konfigurálható analóg áramköri blokkot. Ezen kívül a digitális bemenetek és kimenetek tetszőleges fizikai lábra kivezethetők ezzel is egyszerüsítve a nyomtatott áramköri lap bonyolultságát. A konfigurálható egységeivel további alkatrészeket lehet spórolni, amely kisebb és könnyebb áramkört, kisebb energiaigényt eredményez.

\subsubsection{A környezet érzékelése}

A gépi látás gyors és a térben való jó tájékozódást nyújt a robot számára. Viszont bonyolult a müködtetése és a szoftveres háttere, jóval drágább a kivitelezése, a többi szenzorrendszerekhez képest. Ilyen bonyolultságú és összetett érzékelő hálózat használata nem feltétlenül indokolt egy ilyen robot esetében. 
Ennél egyszerübb, valamint költséghatékonyabb megoldások használatával is jó eredményeket lehet elérni.

Másik két szenzorfajta, amelyről szó esett az ultrahangos szenzor, valamint az optoelektronikai szenzor. Az ultrahangos érzékelő előnye az optoelektronikai szenzorokkal szemben az, hogy a működését nem befolyásolják a fényváltozások, a nagyon tükröződő felületek és a különböző színü tárgyak. Hátránya az, hogy holtzónával rendelkezik, reakcióideje hosszabb, mint az optikai érzékelőké. Érzékenyebb a környezeti hatásokra, az elektromos zajokra. Az optoelektronikai szenzorok nem olyan érzékenyek a környezeti hatásokra és az elektromos zajokra, a zavaró környező fényeket ki lehet szürni és olcsóbbak, mint az ultrahangos szenzorok. Ezeket összevetve, az optoelektronikus szenzorra esett a választás. [4]

Az infravörös szenzorok egy adóból és egy vevőből állnak. Adó például lehet LED, amelyet a robot használni fog, vagy IRED. Vevő is többféle lehet, ilyen a fotodióda, pozíció érzékeny dióda, valamint a fototranzisztor. Ezek közül a foto tranzisztort fogom használni. Az adót és a vevőt úgy kell megválasztani, hogy hullámhosszuk azonos legyen. Ezekből 4-4 darab kerül elhelyezésre a roboton. A robot elfordulásának, valamint sebességének mérésére az útjeladó mellett, egy MPU6050 gyorsulásszenzor és giroszkóp kerül beépítésre.

\subsection{Mechanikai tervek}

A robot alapját, az áramkört is tartalmazó nyomtatott áramköri lap alkotja, a már fentebb meghatározott $45 \mathrm{~mm}$ x $55 \mathrm{~mm}$-es befoglaló mérettel. Az alaplap eleje lekerített, itt kapnak helyet az érzékelők. A robot két kerekü, differenciálhajtásos szerkezet a jobb irányíthatóság érdekében, elöl és hátul fém görgős támasztékok szolgálják a stabilitását. A félgömb alakú fémgörgők könnyü mozgásúak és nem érintkeznek nagy felületen a padlózattal, ezért a súrlódásuk is kis értékü lesz. A két kerék az alap két oldalára kerül besüllyesztve. A két motor súlya a legnagyobb a többi alkatrészhez képest, ezért ezek középre lesznek igazítva, a robot jobb stabilitása érdekében. Egy müanyag lefogóval lesznek rögzítve. A kis hely és a viszonylag nagyméretủ akkumulátor miatt, azok nem az alapra lesznek téve, hanem fölé egy második szintre. Mivel nincs magasságbeli korlátozás és a két rész közötti távolság akkora, hogy beleférjen az elöírt 12,5 cm-es befoglaló négyzetbe. A felső szint müanyag távtartókon nyugszik.

\section{4. Útkereső algoritmusok}

A labirintusnak ismert a mérete és a cél koordinátája a kezdőponthoz viszonyítva. A robotnak fel kell térképeznie a labirintusban a célhoz vezető utat. Több útvonal közül pedig kiválasztani a leggyorsabb útvonalat. A robot előbb egy felderítő kört mehet a labirintusban, ez az idő nem kerül mérésre. Ekkor deríti fel a lehetséges útvonalakat. Az elkészült térkép alapján az éles versenyben a lehető leggyorsabban megpróbálja elérni a célt. A legjobb útvonal megtalálásához több algoritmus is használható, de figyelembe kell venni a számításigényét, mivel egy viszonylag kis számítási teljesítményü, kevés memóriával felszerelt, külső kapcsolatok nélküli mikrovezérlőnek kell az útvonalat kiszámítani.

Ilyen például a Dijkstra algoritmus, amely ha nincs negatív súly az élek mentén megkeresi a legrövidebb utakat egy súlyozott gráfban a kezdőponttól az összes többi pontba. Minden ponthoz tartozik egy tulajdonság, amely azt jelzi, hogy a forrásponttól mennyi a távolsága az ismert legrövidebb úton keresztül. Mivel nem ismert egy út sem első körben, ezért a pontok végtelen címkét kapnak. Ezek a címkék a folyamat közben mindig változnak, ha egy rövidebb út jelenik meg, mint a többi, akkor állandóvá tehető ennek címkéje. A vizsgálat a kezdőponttól kezdődik, ez állandó címkével lesz ellátva. Ezután a kezdőpont összes szomszédját megvizsgálva újracímkézés történik a kezdőponttól való távolságukkal, meg- 
jelölve a címkéjükben a kezdőpont nevét is. Az összes szomszéd címkézése közül a lehetséges legrövidebb út állandónak tekinthető. Következő lépésben egy másik kezdőpontválasztás történik meg és az imént leírt folyamat erre is lejátszódik, ez a folyamat ismétlődik a tényleges legrövidebb út meghatározásáig [7].

A flood-fill, azaz az elárasztásos kitöltés algoritmus lényege az, hogy minden vonalon kiküldi a beérkezett csomagot, azon a vonalon kívül, amelyen keresztül a csomag bejött. A nem kívánt redundancia elkerülésére jó módszer az, ha minden csomag rendelkezik egy sorszámmal, valamint ha az útválasztó rendelkezik egy listával, amelyen szerepelnek a már elküldött csomagok sorszámai. Így ha az útválasztó látja, hogy a listán szerepel a csomag sorszáma, nem küldi tovább azt. Ahhoz, hogy a listán szereplő sorszámok ne gyarapodjanak túlságosan, egy számláló bevezetése célszerü [8].

$\mathrm{Az} \mathrm{A}^{*}$ algoritmus egy heurisztikus h(kiválasztott pont) függvénnyel rendelkezik. Ez a függvény kifejezi a becsült költségét a célig való előrehaladásnak. A h(kiválasztott pont) függvényhez hozzáad egy másik g(kiválasztott pont) függvényt, amely megadja a kezdőponttól a kiválasztott pontig vezető út költségét. Így megkapható az f(kiválasztott pont), vagyis a kezdőponttól a kiválasztott ponton keresztül a célig vezető út legolcsóbb, becsült költsége, ha h(kiválasztott pont)+g(kiválasztott pont) értékkel rendelkező pont kifejtése történik meg elöször, akkor a legolcsóbb út kapható meg [7].

A leggyorsabb útvonal megkereséséhez a robot az A* algoritmust használja, az egyes útvonalak költségét nem csak az útvonal hossza határozza meg, hanem a fordulók száma is, amely lassítja a robotot.

\section{5. Összegzés}

A cikkben egy félméretü Micromouse robot tervezése került leírásra. A szükséges mechanikai és elektronikai megkötések, határértékek meghatározása után került sor a fizikai méretek, tulajdonságok majd az elektronikai alkatrészek meghatározására. A tervezési szempontok alapján egy lekerített első résszel ellátott differenciálhajtású robot született.

\section{Köszönetnyilvánítás}

A cikkben ismertetett kutató munka az EFOP-3.6.1-16-2016-00011 jelü „Fiatalodó és Megújuló Egyetem - Innovatív Tudásváros - a Miskolci Egyetem intelligens szakosodást szolgáló intézményi fejlesztése" projekt részeként - a Széchenyi 2020 keretében - az Európai Unió támogatásával, az Európai Szociális Alap társfinanszírozásával valósul meg.

\section{Irodalom}

[1] Christiansen, C. (2014) The amazing micromouse roars on Spectral Lines. IEEE Spectrum, 51(5), 8. https://doi.org/10.1109/MSPEC.2014.6808441

[2] New Technology Foundation: Rules for Half-size Micromouse, 2010 https://www.ntf.or.jp/mouse/micromouse2011/rulehalf-EN.html

[3] Tondra De, Hall, D.: The Inception of Chedda: A detailed design and analysis of Micromouse, 2004 http://www.physics.unlv.edu/ bill/ecg497/Drew_Tondra_report.pdf

[4] Finan, P.: IEE Micromouse-Chassis Design \& Sensor Strategies, 2000 http://bleuchez.s3.amazonaws.com/micromouse/report.pdf

[5] Cbenson: Drive Motor Sizing Tutorial, Dynamic Tools, 2014 https://www.robotshop.com/community/blog/show/drive-motor-sizing-tutorial

[6] PSoC® 5LP: CY8C58LP Family Datasheet http://www.farnell.com/datasheets/2087452.pdf 
[7] Podobni, K.: Legrövidebb útkereső algoritmusok https://web.cs.elte.hu/blobs/diplomamunkak/bsc_matelem/2009/podobni_katalin.pdf

[8] Tanenbaum, A. S., Wetherall, D. J. (2013) Számítógép-hálózatok; Hungarian Language Edition Copyright Panem Könyvek, Taramix Kft., ISBN 978-963-545-529-4 